\title{
Reforming Teacher Education in England: Locating the 'Policy' Problem
}

\author{
Meg Maguire and Rosalyn George
}

\section{Introduction}

Education policy works by producing sets of ideas that then become part of the 'taken for grantedness' of the way things should be. These ideas become enacted as truths, values, beliefs and practices. However, as Foucault has argued, 'Truth is a thing of this world: It is produced only by virtue of multiple forms of constraint. And it induces regular effects of power' (Foucault 1980: 131). Each society has its own regimes of truth; that is, the type of discourses which it accepts and makes function as true (ibid: 131). But Foucault also wrote that while all societies are typified and formed through the various 'techniques of governmentality' at play at any time in society, these technologies are characterized by 'gaps' and 'limits' (Foucault 1986: 119).

In this chapter we explore the ways in which initial teacher education (ITE) is being reformed in England on the basis of a set of truths, or policy representations that are in circulation about how best to prepare people to become teachers. In exploring how this policy shift is being enacted, the chapter identifies some of the 'gaps' and 'limits' in rhetoric and practice in ITE in England. We also consider three key aspects of current 'techniques of governmentality' driving the reforms that currently shape the main routes into teaching in England. (See also Brant and Vincent's chapter on teacher education in England.) These drivers are the advocacy of consumer choice, diversity seen in the expansion of alternative 'providers' of different forms of pre-service teacher education, and the move to deregulation alongside the erosion of public accountability (Ranson 2003).

In what follows, we draw on a small empirical qualitative study on the experiences of trainee teachers who have 'chosen' between some of the alternative 
pathways into teaching (George and Maguire 2015) as well as some rhetorical claims about these routes into teaching displayed on the various websites that promote these programmes. The intention is to counterpoint these illustrations by turning to the policy analysis approach of Bacchi (2010) to complement and augment Foucault's work on truth and governmentality. Like Foucault's work, Bacchi's analysis starts from a position that policy 'problems' are socially constructed. Rather than governments dealing with 'out there' problems, she argues that they actively construct what is to count as a problem so that the policy answer or solution is the strategy they are seeking to introduce.

In this chapter we argue that the policy problem of teacher education is being constructed out of 'multiple forms of constraint' about the alleged value of some pathways over others and the contested roles of schools and universities in this provision. In contrast, we pose a different representation of the policy problem grounded in the wider social context of failure to recruit and retain teachers in English schools.

\section{The 'taken for grantedness' of reforming teacher education - market forces}

Over the last thirty years the UK has witnessed what Wilkins and Wood (2009: 283) call a 'well-documented revolution in the management of public sector services. One strand of this 'revolution' has been forged by the ubiquitous insertion of marketization into the traditional public sector services; the second strand has been the insertion of an accountability and audit culture. The cornerstone justification for these insertions has been to 'open up' public services, like health, social care and education, to the market place. Against a background of neo-liberalism, which has become the 'taken for granted' discourse of policymakers in the English setting (Furlong 2013), ITE has been subject to a number of reforms to reflect the alleged demands of the market. This dominance of discourses about the efficacy of market forces above and beyond state welfare provision has enabled the insertion of private enterprise into the public sector to provide a model of efficiency, cost-effectiveness and value for money. 'For neoliberalism, public control over public resources should be taken from the "necessarily bureaucratic" state and placed with the "necessarily efficient" private sector' (Saltman 2007: 144). While this pattern is mirrored in all aspects of state welfare provision, our focus is with education and specifically, 
the pre-service preparation of teachers. In this chapter we take the mainstream providers to be those higher institutes of education (HEIs), the universities and colleges, which have traditionally educated teachers, some of them for more than one hundred years, and it is their courses that have been targeted for reform.

This reform process has been tied to the economic pressures of international competition. For example, the white paper The Importance of Teaching (2010: 3) begins with a letter from David Cameron and Nick Clegg, the prime minister and deputy prime minister at the time, emphasizing that

what really matters is how we're doing compared with our international competitors. That is what will define our economic growth and our country's future. The truth is, at the moment we are standing still while others race past.

In these changing economic, political and ideological conditions, the purpose of schooling and the practices of teaching have to contribute to a productive workforce and enhance Britain's competitiveness. Teachers need to be 'trained' to prepare 'ready-for-employment' school leavers who are alert to opportunities, 'rendering people as assets to be managed' (Trippestad 2014: 63). Education has strategic importance because it is responsible for producing a highly skilled and flexible workforce, which is indispensable to sustainable economic growth and Britain's competitive advantage in a global world. From this position of market-orientated neo-liberal thinking, a more open and competitive context is generated in which teachers and schools have to be made more responsive to external outputs and measurement and more receptive to the wishes of the consumer (Apple 2001). To an extent schools are repositioned as business units that compete with each other to ensure they have progressively good cohorts of students that are 'most likely to perform well in relation to external measures' (Ball and Youdell 2001: 44)

Alongside the marketization of schooling runs another 'truth' that 'induces regular effects of power' (Foucault 1980: 131) and this is the notion of flexibility in deregulating teacher education provision and expanding diverse programmes of ITE. New routes into teaching are being produced, as we discuss later on. However, there is a contradiction in this proliferation of pathways into becoming a teacher; while some pathways seem to be flexible and autonomous, others have become far more centrally controlled. In the centralized pathways, there are far more stringent controls of both inputs and outcomes of teacher preparation produced through a discourse of 'standards' as the dominant narrative. This discourse of standards imposes and produces a specific construction of the 
qualified teacher or the good training provider and provides constant pressure for providers of the mainstream pathways to conform to the same model. Through the conflation of 'standards' and 'common sense', the government is able to justify its agenda to enhance Britain's competitiveness in the world market. In this reworked construction of the teacher, practical in-school experience is foregrounded. Indeed, in its white paper of 2010, the government stated its intentions to 'reform initial teacher training so that more training is on the job' (DfE 2010, para 2.6.: 20). In consequence, new partnerships between the HEIs and the schools, where the schools are in the lead, typify the English teacher education setting (Whitty 2014).

Almost a decade ago, Hursh (2005: 11) pointed out that one 'neo-liberal policy contradiction is between the notion that markets are self-regulating and the reality that they require significant governmental intervention'. Much of the government intervention into (some forms of) ITE is managed through the rhetoric and technologies of accountability. Specifically in relation to reforming ITE there is evidence of a conflicted and contradictory approach towards accountability. A highly interventionist stance towards mainstream teacher education has led to this provision being subjected to greater controls and regulations when it is provided by the higher education institutions (HEIS) a process that has been in play over the last three decades (Murray and Mutton 2016). The inspection regime, as embodied by the Office for Standards in Education (Ofsted), works with a certain set of assumptions about the way in which effective teacher training providers should act. Ofsted has the power to judge whether or not HEIs are 'successful' course providers based on the centrally prescribed 'standards framework. The inspection process has a powerful impact on the mainstream HEI providers of teacher education because a negative outcome of their inspection can lead to diminished funding and a reduction in the allocation of student numbers. In the current policy climate, schools work in partnerships with their local HEIs and take greater responsibility for the preparation of teachers. However, they do not take an equal share of responsibility should the institution's inspection be unfavourable - a form of 'HEI blame' rather than 'system blame'. Simultaneously, the school-based routes and pathways enjoy far less restrictions and far less regulated spaces in which to provide for teacher training. What we see in this disjunction then, illustrates a 'gap' in accountability between different provisions of ITE, one core tactic in the 'techniques of governmentality' (Foucault 1986: 119). 


\section{The 'taken for grantedness' of reforming teacher education: Alternative providers and unexpected outcomes}

Turning now to another dimension of markets in teacher education, the idea is that innovative organisations will step up to provide public services in new ways. And competition will force performing providers to up their game or face failure' (Blatchford and Gash 2012: 5). In this shift to decentralization, responsibility for success lies with the new providers, and government stands at arm's length in terms of its obligation to provide teachers. The alternative providers in England include clusters of schools, academy chains and third-sector providers such as Teach First and the ARK chain of schools (Junemann and Ball 2013; Ellis et al. 2015). Third-sector providers are independent of government and include voluntary groups such as churches and community organizations, social enterprises and co-operatives. They are philanthropically motivated and are usually 'not for profit', although they generally have to produce profits to be reinvested to sustain their growth. The alternative routes into becoming a teacher include forms of school-based training where the school/academy chain takes the lead or works in different forms of partnerships with HEIs. These routes also include a range of specialist training programmes such as Troops to Teachers, Teach First and Researchers in Schools (https://getintoteaching. education.gov.uk).

The previous senior minister for education, the secretary of state, Michael Gove (2010-15), regularly demonstrated his scepticism about the role of university education departments and higher education's place in training teachers. His view was that over time, universities had gained a form of producer capture (where teacher education was more related to the needs and interests of the universities rather than the consumers - the schools and the trainee teachers). Even before Gove's intervention into education policy and governance, moves had been made to introduce forms of market forces into teacher education, to break producer capture and to foreground the classroom rather than the lecture hall as the key site of learning (Gilroy 1992; Furlong 2005). Under Gove, however, the new policy imperatives for training teachers were uncompromising, particularly in the way in which they spoke of HEIs:

School Direct also allows schools to shop around between universities for the best support for trainee teachers. That means universities have to shape their education departments to the practical needs of schools instead of the whims of 
ideologues. It also means that universities have to think hard about where they direct their research in education departments. (Gove, Speech 2014 our italics)

These developments, then, mean that currently in England, there are two dominant forms of teacher education and these can be categorized as either school led or university led. The Department for Education (DfE) has a website, Get into Teaching, that details the routes available and explains:

There are plenty of great ways to make a difference by getting into teaching. How you go about it will depend on your personal circumstances, qualifications, and the subject and age group you want to teach. (https://getintoteaching.education. gov.uk/explore-my-options? emooption=1)

There is also a range of what are called 'specialist courses' and these are perhaps more typical of alternative provision elsewhere. As the DfE website states:

There are a number of additional training options available if you're a Service leaver, an experienced teacher or finishing a $\mathrm{PhD}$. If you have a 2:1 or higher, you're also eligible to train to teach with Teach First, a charity that places exceptional graduates in schools in low-income areas to become effective leaders. (https://getintoteaching.education.gov.uk/explore-my-options/specialisttraining-options)

Service leavers do not have to have a first degree, experienced teachers without teaching credentials but with experience can become accredited and those with a $\mathrm{PhD}$ can attract a well-resourced bursary to encourage them to move into teaching after their research degree. Teach First, a spin off from Teach for America, offers a two-year Leadership Development Programme that aims to place trainees in 'hard to teach' settings where they stay for two years. Teach First is 'a vocal and energetic campaigner for change, leading the conversation about educational reform at all levels, and working with government, businesses and other charities to end educational inequality' (http://graduates.teachfirst. org.uk/why-teach-first/what-has-change. All these new providers contribute to what Junemann and Ball (2013: 423) call 'the ongoing and increasing blurring of the welfare state demarcations between state and market, public and private, government and business. This move to deregulation and marketization has not only been fuelled by ideologies of market forces and empowering consumers, it has also been driven in part by expediency.

This is because there has been, and currently is again, a 'crisis' in teacher recruitment in England (although it may be more appropriate to talk of a 
retention crisis rather than a recruitment problem). One factor involved in this 'crisis' may well be the reported low morale of teachers (NUT 2015); another factor, according to Estelle Morris, Labour Secretary of State for Education (2001-2), may be the various changes to teacher education that have created instability in the system (Morris 2015). In 2012, the secretary of state for education announced plans to give schools greater control over the recruitment of trainee teachers in England with an intention that by 2015 over half of all training would be delivered by schools. Since this declaration, the allocation of places has shifted away from HEIs towards schools-based programmes like School Direct. However, data provided by Universities UK found that recruitment to the School Direct route into teacher training in 2013-14 fell short by one third, whereas university recruitment exceeded 90 per cent of its allocated places.

Nevertheless, this aspiration for a school-led system continues to be reinforced, with allocations for School Direct being increased by 13 per cent and those for university-led places being reduced by 7 per cent. Furthermore, the English Government has adopted a new allocations policy for 2015/2016 recruitment by deregulating the whole system. At the time of writing, there are no longer allocations for different providers but an allocation for the whole country. When this national target is reached, in either phase (primary or secondary), school subject providers will be told to stop offering places (Husbands 2015). For example, recruitment to university-led training in history and physical education had to stop within the first few weeks of applications. At that time School Direct had over hundred places still available. Interestingly, as Wilkins (2015) observes, it is widely acknowledged that attracting candidates to Science, Technology, Engineering and Mathematics subjects is difficult, but despite the fact that university-led providers are far more successful in supplying qualified teachers in these subjects, these subjects have been reduced overall within the core allocation of HEI trainee numbers.

The positioning of schools within an ITE marketplace is arguably to promote choice for applicants in the route they choose. However, in placing caps on the number of students that universities are allowed to recruit while setting minimum targets for school-led providers, the government has skewed the market and encouraged schools to recruit above any set targets (Harris 2015). The concern is that as the government pursues its ambition for school-led teacher training at this current pace of change, HEI-led teacher education may become unsustainable and may be forced out of the ITE market with any unused places taken up by other providers. Schools will not close if they fail to recruit trainee 
teachers. (For more discussion of university and school- led teacher education, see the chapter by Dickinson and Silvoinen comparing Finland and England.)

\section{And the consumer of new forms of teacher education?}

In England, a number of studies have explored the contribution, and some of the complexities, of the more traditional university routes (Beck 2008; Furlong 2005; Ellis 2010). Other researchers have concentrated on some of the alternative routes into certification (Hutchings et al. 2006; Mujis et al. 2010) and currently some research teams are looking at the impact of wider political and economic changes for ITE (Furlong 2013; Horden 2014). Yet, to date, little is known about the perspectives of the consumers of all these new pathways. Little is known about the actual choice making of current trainee teachers and their reasons for selecting particular routes into teaching. Little is known about how they perceive and describe the advantages and disadvantages of their chosen pathways. What are their experiences of these different routes that are currently available in England? Does marketization 'deliver' for the trainee teachers?

Our small-scale study explored some of the main reasons for the choice of pathway of a group of twelve students aspiring to be teachers who were following either school-based routes or what we call the 'mainstream pathways of the HEIprovided Post Graduate Certificate in Education'. We wanted to investigate why trainees chose their particular route into teaching and the extent to which they considered their particular pathway as the most effective one for becoming a teacher. In order to address these questions we asked our respondents to reflect on how their educational journeys had contributed to their choices of programme, impact of teachers in the family, influence of peers, etc. We were also concerned to explore the trainees' individual experiences of their chosen route and asked them to highlight the elements that either contributed or hindered progress. Lastly, we wished to explore how far our respondents would advocate for their chosen pathway over others.

We considered the reasons given by our respondents for choosing their pathway into qualified teaching status through two broad categories of extrinsic and intrinsic reasons and motivations. We recognize the complexity of their choosing and the overlapping and interwoven factors that are involved in this process. 


\section{Extrinsic motivators for choice}

Some of our participants' reasons for choosing a particular form of ITE were straightforwardly to do with accessibility and issues related to their housing and transport. In a large and expensive city like London, these sorts of factors can constrain occupational choice-making for many people, not just for teachers. Those who were applying through the School Direct Routes (salaried and unsalaried) have more capacity to choose than their Post Graduate Certification in Education (PGCE) peers in the more traditional university programmes - an important part of their application involved applying to a particular school or group of schools - and this means they can directly choose their location and the area in which they will be doing their school placement. PGCE trainees, on the other hand, will be offered places in schools where their institution has partnerships and while they may have some capacity to exercise choice. (Those trainees who are parents or who have caring responsibilities will generally be placed first and nearest to their homes as far as is possible.) School Direct entrants get to select their main training school as part of their initial application, which offers advantages and is extremely attractive in terms of practical issues of manageability. 'And I could walk there, I could walk to school, it takes me twenty minutes from my flat' (Susan).

For some of our respondents, mainly the older trainees who had selected to follow the School Direct pathways, another key driver for their choice related directly to issues of labour market pressures, occupational security and future prospects. Some of these older trainees had experience of sometimes precarious and insecure work and were now turning to an occupation that they thought presented them with security as well as an opportunity for advancement in a professional and structured career. These reasons are also going to be part of why other trainees choose teaching as an occupation regardless of the pathway/ route that they select. However, when coupled with the prospect of a salary while undertaking training, as two respondees separately volunteered, It's a no-brainer (Claudine and Susan).

Others gave a rationale for choosing their pathway that related to matters of the status and prestige that they believed would accrue to them after the successful completion of their programme. For example, some of our respondents argued that attending a certain higher education provider would lend a certain degree of prestige to their profiles. 'I think the reputation and the ... just the overall reputation of the institute as a whole, I think was a big draw for me' (Frances). 
Trainees on the more traditional PGCE will choose (or at least nominate) their institutions rather than choosing their school placement and it may be that the reputation of the institution (called the 'provider' in government discourse) will drive choice to some extent for many trainees regardless of their pathways. However, for School Direct trainees, the capacity to choose their placement school, where they will spend the majority of their time, is a practical advantage, as we have already seen.

\section{Intrinsic rationale for pathway choice}

Some of our respondents, who had clearly considered their choice of institution as one of the key variables in their portfolio of choosing, had come to their decisions for sometimes less extrinsic reasons. Jean, for example, had chosen School Direct because it offered her a chance to train to teach in her part of London, but she had also considered the institutional side of the programme and the people she would be working with in the university. Like Frances, she was attracted to what she saw as a high status provider, but one where a certain philosophy and ethos would be promoted through the work of a highly respected academic in the field.

Our respondents did not have one sole reason for choosing to become a teacher on a certain route: their rationales were frequently multifaceted which is why we describe a 'portfolio of choice' in relation to their rationale for choosing. What was evident in what all of our respondents had to say was that they also had some powerful intrinsic reasons for choosing to teach more generally - reasons that are well documented in the research literature on becoming a teacher (Richardson and Watt 2005; Manuel and Hughes 2006). They were committed to sharing their love of their subject with young people; they wanted to 'make a difference'. As Jean says, she thinks she was accepted on the programme to become a teacher because of her enthusiasm:

They saw how much I love teaching and how much I love children and being around them and watching them become these, like, amazing adults that they have the potential to be.

When it came to participants' reasons for choosing to become a teacher through the traditional HEI-based route of the PGCE, our participants had a set of powerful arguments that explained why they made the choice they made. Emily, 
for instance, decided to take up a place at a university and do a PGCE. She explained her decision very carefully:

I was quite keen to do university-based training. I think because I'm quite academically inclined I thought it would make it more interesting, the course. I was aware that I wouldn't want to just train in one setting, I wanted to see different practices. I just thought it would make me a better, maybe more critical teacher if I trained through a university and saw multiple settings.

Pierre, who had chosen to do a PGCE in modern foreign languages, believed that studying to teach at a university was going to be better route for him, too. $\mathrm{He}$ argued that school-based training was perhaps more to do with covering classes rather than helping develop the good teacher:

The university's mission is to produce outstanding teachers, the best they can be. School based training has other priorities which lead to students being put in front of a class without the security of support enjoyed by PGCE students.

Some of the School Direct participants (salaried and non-salaried) were concerned about the university element. For example, Anna said she 'couldn't face university again' and Laura said that her university element of School Direct was 'rubbish, everything was a bit too late. They only did lesson planning in November and I'd been planning since September.' However, most of the participants from all of the pathways saw the university-based part of the programme as valuable. As Jean put it, 'I felt there was still a lot for me to learn.'

Currently the English polity is keen to contract out as much state provision as possible to the allegedly more efficient business community or to third-sector providers (Ball 2015). In the case of teacher education, school experience and the workplace learning it supports are a critical part of becoming a teacher. However, as some of our participants have stressed, they wanted their professional development to be widely applicable so that they could be prepared to work in different settings. They indicated that they were unhappy about simply being inducted into one way of working or being used to bolster staffing needs in a school, something they had not anticipated when making their choices. Melanie, who felt completely at a loss from the outset of her course, stated:

The first week I was in my school, they put me in a class, I was teaching two double lessons; I'd never taught in my life and they just left me in there on my own without even another teacher in the room and this happened very early, the first week. 
Paulina also saw being tied to a single school as a disadvantage:

Sometimes I feel that schools can be a bit like, 'Oh you're working for us so you've got to do everything we say or we won't pass you.'

While being able to choose a route into teaching seems to be an attractive option for aspiring teachers, and indeed the data suggests that our respondents were active choosers, the data also suggests that some of our respondents ended up in a situation they found impossible to escape from:

And I am still teaching, even now, those same classes, and one of them is a Year 8 class that I will never win over. I'm a terrible teacher in those lessons. They don't even listen to me, it is chaos; they are so disrespectful to me (Melanie).

It would seem that our participants sought to have their professional needs responded to in a thoughtful, analytical and caring way and from what these participants have said, there can be some constraints and limits to 'learning on the job'.

\section{Discussion}

As Sahlberg (2006: 263) has put it, 'Business leaders, politicians and educators are looking for solutions for improving economic competitiveness and thereby economic growth. Market values like productivity, effectiveness, accountability and competitiveness are increasingly being embedded in global education reforms.' For these sorts of reasons, education is constantly under review; education policymakers constantly scan international league tables and access new curricular innovations and reforms from higher-scoring nations in order to ratchet up their own provision; they engage in policy borrowing rather than policy learning (Chakroun 2010) In many ways, perhaps we are all suffering from too many educational reforms where change is the only game in town!

To this point we have focused on one aspect of this policy overload: the reforming of teacher education in the English setting. As Hulme (2016: 37) puts it, 'A repertoire of global reforms has sought to increase control over teachers' work and performance,' and one of the most basic ways in which this control can be exercised is through regulating the ways in which teachers are trained or educated for their work in schools. The reform of how teachers are prepared, trained and educated for their work is now a central plank in any attempt to usher 
in changes in schools - first, reform the teachers and reconstruct their work, their understandings and their subjectivities and second, other reforms that overlap with these new sensibilities will follow on, somewhat inevitably (Cochran-Smith et al. 2011). 'Fixing' teacher education will 'fix' other educational problems.

For some time now in the English setting, policymakers and politicians have endeavoured to reform teacher education provision. Through the generation of various 'regimes of truth' (Foucault 1980: 131), at various points in time, English teacher education has been seen as either too theoretical, unconnected to the world of the schoolroom, under the control of left-wing ideologues in universities, lacking in rigour, sometimes too influenced by research and, at other times, not sufficiently aware of evidence-based best practice (Furlong 2013). While English teacher education has always been susceptible to reform, since the 1980s there has been an acceleration in the depth and reach of a swathe of almost non-stop reforming moves that are well documented elsewhere (Furlong 2013; Whitty 2014). However, what we have concentrated on in this chapter is not so much the actual reforms themselves, but the ways in which these policy reforms to teacher education have been justified, explained, made to seem almost irresistible and certainly necessary to the global markets project in education. What we have also tried to explore, albeit in a limited manner, is how one group of underresearched consumers (trainee teachers) navigate this market setting.

We started this chapter by arguing that education policy 'works' when it ensures that the core ideas and strategies and plans and tactics that make up the specific policy become accepted as part of the way things are, part of the 'common-sense' of how to best organize and provide education. As education policy is 'implemented' and translated into practice, it becomes enacted as truths, accepted practices, values and beliefs - the best way to do something in response to a particular problem. In the case of ITE, this can be seen in the growing number of possible routes into teaching and the embracing of these reforms by head teachers and schools. However, we also argued at the start of this chapter that according to Foucault (1980: 131), 'truths' are socially constructed and 'produced only by virtue of multiple forms of constraint'. We have claimed that the construction of a set of narratives about the alleged weaknesses in teacher education has been woven together to articulate what the policy problem is taken to be in this context. This is how the policy problem is being represented (Bacchi 2009).

In many of the more positivist approaches to policy work (Swann and Pratt 2003), it is possible to trace the 'emergence and strength of a problem-solving 
paradigm in a wide range of sites, a paradigm that assumes that "problems" are readily identifiable and objective in nature' (Bacchi 2010: 1). Thus, the policy problem is seen to lie in the need to raise attainment in schools and to produce what the economy demands. The 'right' sort of reforms to teacher education will produce the 'right' sort of teachers who can deliver these necessary reforms in the nation's schools. In this way, as Bacchi explains, governments 'create 'problems', meaning that they create particular impressions of what the 'problem' is so that the policy answer or solution is the strategy they are seeking to introduce, and here we are thinking of neo-liberal drivers.

From what we have argued in this chapter, we have highlighted a particular 'version' of what is to count as the policy problem in teacher education in the English setting. We have also tried to start thinking about how this version of the 'policy problem' of teacher education has been normalized and become taken for granted as a 'regime of truth' (Foucault 1980: 131). From the commentary in the white paper (2010), it is possible to identity a 'truth' about teacher education and the problems that need to be reformed. However, as Bacchi has pointed out, the ways in which policy problems are being represented need further interrogation. First, there is the question of the way that the problem is represented as the need for more school involvement? Does this experience improve the effectiveness of teacher education? What should be the role of school experience (Ellis and Orchard 2014)? And secondly, is the policy problem really to do with a lack of marketization in teacher education?

Let us just take the argument that teachers learn best in schools and need to spend more time training in school placements. Trainees on the mainstream PGCE share an almost identical experience to that of the School Direct (unsalaried) trainee, and both spend a similar amount of time based in schools. The barren argument over which setting should dominate displaces or at least is a 'devaluation of the overall place of universities in supporting teacher learning ... and of research-informed knowledge' (Murray 2016: 188). This is perhaps a more taxing problem for policymakers. While much of the English policy rhetoric stresses what Pitzer (2014: 128) calls the 'authority of experience', what we learnt from our trainee participants is that they value a wide range of experiences. That is, as Emily explained above, they value access to critical tools and current arguments in education-based research as well as the capacity to test out and extend their pedagogic practice in a range of carefully supported environments. While our sample is small, what was of concern was the perception of some trainee teachers that in some cases, schools were presenting constrained ways of learning to become a teacher, as Claire said; 'They made it very clear that the 
institution were meddling in their system, that this is the way they do it and they're perfectly within their rights to do it this way.'

In terms of our second question; 'Is the policy problem really to do with a lack of marketisation in teacher education?', it is critical to bear in mind that 'markets cannot do everything, however, and should not be expected to. Externalities and public goods test the scope of markets' (McMillan 2002: 227). From what our trainees said, it was evident that practical matters played a part in their choosing and decision-making, but they all were motivated by more intrinsic reasons related to their concerns about public service, social justice and the common good. They were pleased to have more control and choice over what route fitted best with their circumstances, but they all quickly realized that this choice was limited; they were able to choose their school to fit with other aspects of their lives, but once in school, they were susceptible to all the complexities of life in the workplace, matters over which they felt they had very little control or indeed much choice. Indeed, those on School Direct salaried pathways seemed, in some cases, to miss the buffering effects of external partners such as the HEI providers (George and Maguire 2015).

In the English market place of teacher education, there is diversity, as we have detailed in the range of programmes and pathways into the profession. One matter that we have not fully dealt with in this chapter concerns the financial context. The government funds teacher education (through a complex blend of bursaries, student loans and funding from taxation), and the lead institutions (HEIs, schools and alternative providers) attract funding for places for trainee teachers. In an open market, providers compete with one another for business; in ITE, the market is regulated as noted above, and there are some preferred providers and complex technologies that exert more controls on some of the pathways rather than others. If HEIs are not allocated enough places, they will be forced out of the ITE market and any unused places will be taken up by other providers. Schools will not close if they fail to recruit trainee teachers. So, to some extent, the market is uneven and skewed, as we have already illustrated in this chapter when we explored current policies of how places are allocated to different pathways/providers.

In terms of structural matters, it seems to us that something as central to national well-being as the education of prospective teachers cannot simply be left to the market to decide. There are practical and systemic questions about supply and demand such as ensuring that teachers are being trained for locations where they are needed and where there are jobs. There are questions of social justice and issues of representation; in a decentred and deregulated system, how 
do we know that we are recruiting a diverse teaching force that represents our cosmopolitan society?

We have space for one last question and want to turn to a matter of a more theoretical nature that we think needs to be addressed. In the deregulated ITE marketplace (deregulated that is for some providers but not the mainstream ones), what may be happening is that current policy is aiming to reconstruct a new type of teacher - steeped in their classrooms and perhaps less exposed to broader questions about aims, values and even alternative pedagogical practices. Foucault argued that policies create subject positions that are then taken up by different individuals. His view 'suggests that policies, through the subject positions they create, shape our subjectivities (to an extent)' (Bacchi 2010: 6).

In the case of ITE reform in England, if the 'problem' relates to the place of training and alleged claims of lack of rigour, irrelevance and so on in HEIs, then the 'new' teacher trained more and more in school may eschew a more complex view of their role or simply take up the status quo as they experience it in their school. This, for example, may or may not be a 'good' thing if the teacher then moves to a different school, with a different intake, and with a different pedagogical approach. However, as Bacchi (2010: 6) points out, 'Political subjects may either take up or refuse "subject positions." And from what some of our research participants had to say, they held evident commitments to becoming enquiring teachers and extended professionals regardless of the routes and pathways they had chosen. They were clearly not displacing the role of HEIs in helping them in becoming effective teachers and neither were they unaware of the complementariness of their experiences in their schools. This is what Foucault (1981: 13) meant when he said that we can challenge who we are asked to become: 'Critique doesn't have to be the premise of a deduction which concludes: this is what needs to be done. It should be an instrument for those who fight and refuse what is.'

\section{'Locating' the policy problem?}

Finally, what we want to do is return to how the problem of teacher education could be represented differently.At the start of this chapter we suggested that the policy problem of ITE was being represented as current practice needing to be 'fixed' by schools and other providers. We want to conclude by posing a different representation of the policy problem grounded in the wider social 
challenge of the failure to recruit and retain teachers. Currently there is a significant shortfall in the recruitment of teachers (NUT 2015). Perhaps even more troubling is the massive problem of retention where over forty per cent of teachers leave the profession within the first five years (Wilshaw 2014) and there is evidence that teacher shortages are still increasing (Ward 2015). Our point in this chapter is not to replace one policy 'problem' with another; rather it is to try to demonstrate that if the problem is represented in one way, other matters that might be involved get marginalized. 'Locating' the policy problem is not about teasing out what is the 'best' problem to fix; it is about the recognition that taking the problem in a particular way means that other versions of what could be seen as a problem simply become displaced. 
